SHS Web of Conferences 6, 03004 (2014)

DOI: $10.1051 /$ shsconf / 20140603004

(C) Owned by the authors, published by EDP Sciences, 2014

\title{
Research on Food Quality Security of China's Food Import and Export
}

\author{
Liu Pengling, Han Baoxin, Luan Jingdong \\ College of Economic and Management, Anhui Agricultural University 230036 Anhui Hefei, China
}

\begin{abstract}
This article researches quality and safety of food at home and abroad on the basis of present situation, cause and effect, from the point of import and export of food quality and safety in China, by combining with economic theories and empirical analysis, from a macro perspective study of China's import and export food safety issues impact on economic and social development, and study the experience of other developed countries advanced management experience in the quality and safety of food imports and exports. Finally, after the combination of the analysis, make recommendations to protect China's import and export food safety measures and provide policy proposals.
\end{abstract}

Keywords. food quality and safety; China's foods import and export; foreign trade

Food quality and safety is as human in the process of continuous development of economy and society, new problems and new contradictions, foodborne disease cause of mortality is rising every year. Since China's reform and opening up, China has been a rapid development of food industry, in the last decade of 20th century, China's food industry to maintain the fast growth of $10.4 \%$ annually, obtained the unprecedented development. After entering the new century, China's food industry, especially the import and export food trade external macro environment and internal industrial structure, great changes have taken place. In 2010 China's total import food from 183 countries, food exports to 216 countries, the export of food qualification rate reached $99.93 \%$, imported food not the percent of pass is up to $2.17 \%$, to detect the total of 13800 batches of unqualified food.

\section{China's import and export of food quality and safety problems cause analysis}

\subsection{Economic analysis}

\subsubsection{The food market information asymmetry}

Exist on the food market "producers, sellers and consumers" of the supply chain, the producers relative to the other two of the most food information advantage, sellers also have food information advantage relative to the consumers. With the advantage of information economic subject will use its information advantage to speculative behavior, such as producing or selling fake and shoddy, substandard food quality safety, and no information superiority interests damage caused by the party, lead to food quality and safety incidents (as shown in figure 1). 


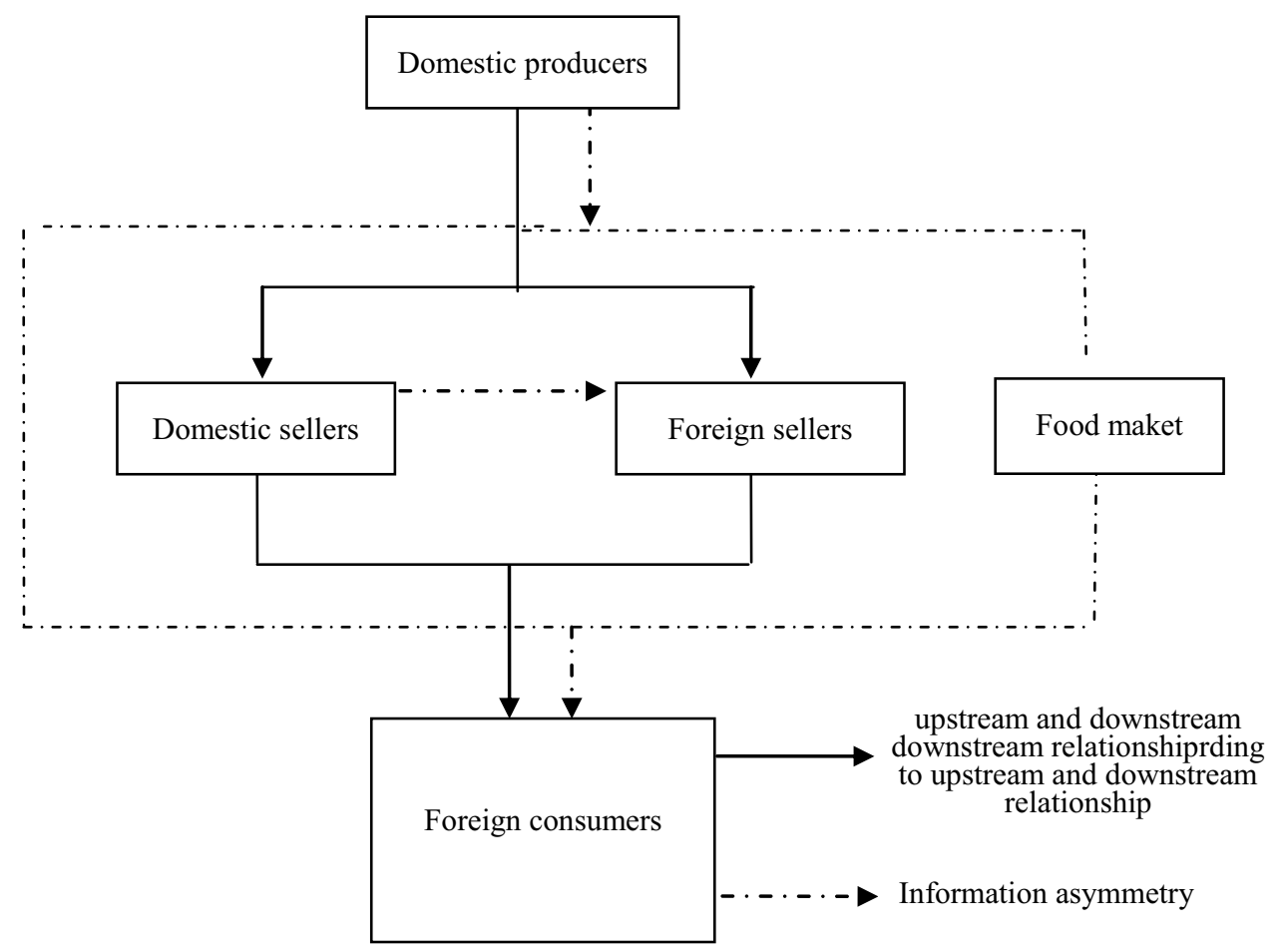

Figure 1. The asymmetric information on the food market

In the import and export food market regulation and under the condition of asymmetric information, both the seller and the buyer clear food products on the market there is good or bad, and can according to their classification and extrapolate the usual trading habits of food quality. Food market, meanwhile, the seller knows clearly the stand or fall of their products, in the process of trade can try the profit maximization of the buyer's decision in the decision-making, so a lot of food, the seller will be shoddy, sale low quality standard products, which reduces the average food market product quality standards; And the buyer in the purchase to low quality or substandard food, will realize the average decline in the quality of the market, will reduce the buyer's expectations of the market, forming a market failure.

\subsubsection{The food market of externalities}

There are two main types of external manifestation of the food market: one is the food in the market for high quality food producers to consumers and low quality food manufacturers to form positive externalities. 2 it is food low quality food producers to consumers in the market and high quality food manufacturers form of negative externality. For example 2006 "of turbot carcinogenic event" happened in China, because the behavior of the individual small retailers at first, but eventually lead to huge losses of turbot market across the country. 

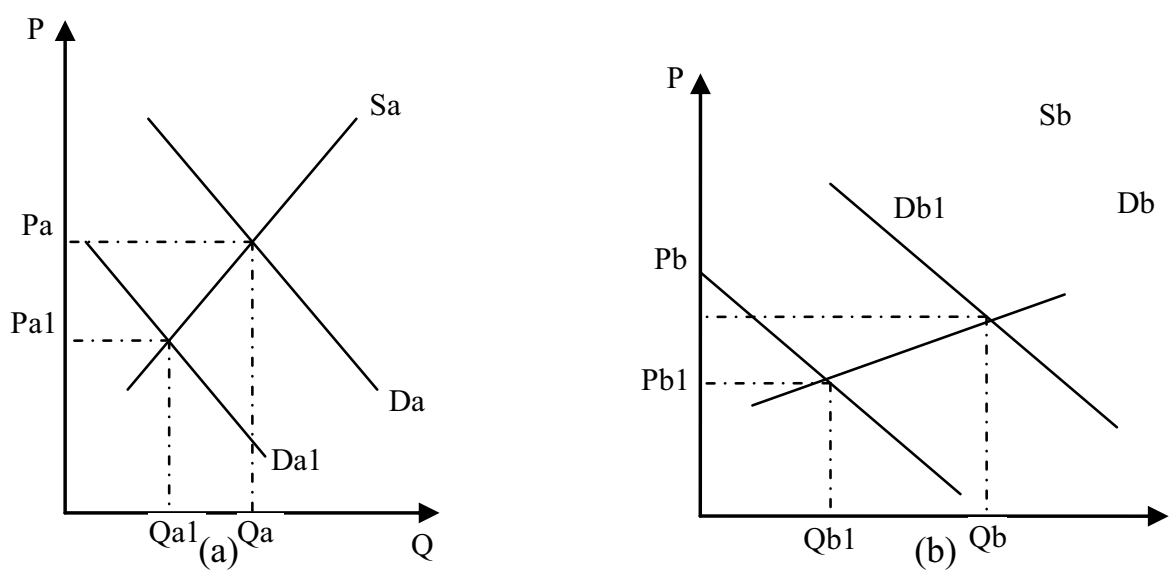

Figure 2. The externality analysis on food market

Figure 2 (a) food quality standards high market, including Sa curve represents high quality food supply curve, Da curve represents the high quality food demand curve. Figure 2 (b) it means lower market food quality standards, including Sb curve represents the low quality food supply curve, the $\mathrm{Db}$ curve represents the low quality food demand curve. In high food quality standard on the market, the enterprise production cost is higher, so products have to $\mathrm{Pa}$ at the higher price sale, buyers and sellers on the market information is symmetrical, the price customers are willing to accept, so the market equilibrium price for $\mathrm{Pa}$, equilibrium quantity for Qa. The same analogy, food quality standards for its low market equilibrium price for $\mathrm{Pb}$, equilibrium quantity for $\mathrm{Qb}$. The food market in most cases, however, information is asymmetric, low quality of food production enterprises can take advantage of the positive externalities of high quality food production enterprise to obtain benefits, consumer is aware of the food quality and safety standards will reduce the security of the market after more and more low expectations, thus high quality food market demand curve, which is shown in figure 2 (a) shows the demand curve for Da1 by Da changes. High quality food enterprise itself into a larger, production cost is higher, not willing to adjust their food supply curve, so the equilibrium price $\mathrm{Pa} 1$, equilibrium quantity Qa1, apparently $\mathrm{Pa} 1<\mathrm{Pa}$, Qa1 $<\mathrm{Qa}$, visible high quality food production enterprise profitability. Low quality food production enterprise, on the other hand, the market share increases, the demand curve from figure 2 (b) the $\mathrm{Db} 1$ to $\mathrm{Db}$, respectively, the equilibrium price and quantity, and low quality food market total revenue increased.

To sum up, can find the food market of externality caused the food quality standard reduce deterioration on the market. If the government does not intervene, the food market environment will deteriorate further, food safety incidents will emerge in endlessly. The externalities of the food market reduces the efficiency of social resource allocation, is no guarantee for the consumer health and food safety, is another big reason why food safety problems.

\subsection{3 trade protectionism}

According to (H - O) theorem, a country should produce and export the country's rich elements of the product. China's large population, cheap labor, so the production of labor-intensive products and exports have strong comparative advantage in international trade. China's labor intensive food production cost is low, have the price advantage, the export of agricultural products, aquatic products, fruits and vegetables has occupied a large share, and gain greater initiative in food export trade.

However, some western developed countries, in order to protect the domestic food industry development and its food in the domestic market against competition from Chinese goods, often take some non-tariff trade protection measures to limit exports of our country's food. For example, by strict food quality inspection standards, in the name of protecting domestic agricultural production to reduce 
imports, such as green barriers. Since our country joined the world trade organization in 2001, China trade remedy investigations, a total of 692 cases, involving total about $\$ 40$ billion. Statistics show that all of 2011, China's export food had nearly 100 protectionist measures, and since 2008 has accumulated up to 600. Because abroad for China's food export trade protectionism is becoming more and more various, often cause our country export food quality and safety standards for below new testing standard and food quality and safety problems, caused a big loss. Below with the method of game theory, to analyze the trading countries adopt the intrinsic motivation of trade protectionism.

Hypothesis: (1) the country A and country B carry on the division of labor according to their comparative advantage and trade. A country has comparative advantage in the production of A product, country B in B products have comparative advantages; Separately from each other between the two countries to import their products at A disadvantage, has the country A product imported from country $\mathrm{B}$ B, country B imports A product from A country.

(2) the country A and country B only be allowed to adopt protectionist measures to restrict the export of the other party, so in this case, A and B can adopt the strategy of the two countries each have two kinds, namely to trade protectionism and do not take trade protectionism. The strategies of the two countries is different, there are four kinds of results, using matrix chart (Figure 3) :

Country A

With trade protection measures

B Country

No trade protection measures
With trade protection measures $\quad$ No trade protection measures

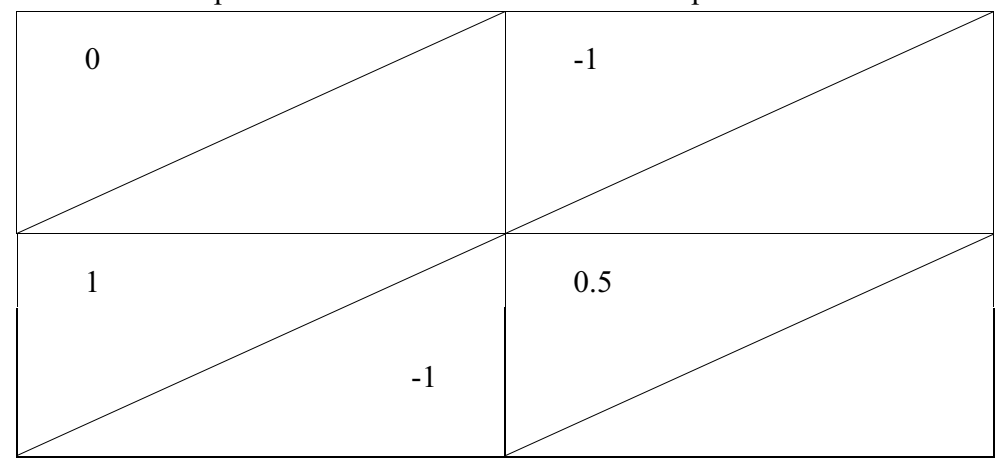

Figure 3. The Matrix chart of results between A and B country in use of trade policy

Results: (1) both A and B have protectionist measures, the trade between the two countries benefits to zero (top left);

(2) A country do not take protectionist measures, country B to take, the welfare of the country A loss 1 unit, the welfare of the country B to obtain 1 unit (top right);

(3) the country A protectionist measures, country B do not take, 1 unit of trade benefits in country A, country B loss 1 unit of trade benefits (lower left);

(4) both A and B have not take trade protectionism measures, the two countries can achieve 0.5 units of trade benefits (lower right).

Obviously in the international food trade competition, the pursuit of maximum profit driven, take the lead in protectionist measures can gain more benefits.

\section{2 domestic reasons analysis}

\subsubsection{Unsafe food production process}

With the continuous expansion of China's import and export food trade, participate in the increasing competition at home and abroad, forming a batch of taking shape, small impact, food quality of formal large food companies. This part of the enterprise strictly abides by relevant international health standards, quality products with high added value and performed well in terms of export inspection and quarantine results. Statistics show that in 2009 and 2010, China's exports of goods 11.032 million 
batch and 13.054 million respectively, the percent of pass is $0.15 \%$ and $0.14 \%$, respectively; Japan to $20 \%$ since China's food, the high proportion of sampling qualified rate is as high as $99.74 \%$, higher than the same period of sampling percent of pass of food imported from the United States and the European Union.

\subsubsection{Food safety laws and regulations system is not mature and perfect}

As early as 1995, China promulgated the food hygiene law, and law as the criterion management of food safety problems, however, with the domestic and international food safety situation is complicated, the food hygiene law clearly already can not adapt to food quality and safety problems of new contradictions. In February 2009, "food safety" arises at the historic moment, just at the level of legislation in our country completed from the "food hygiene" to the "food security" the concept of transformation and the construction of the foundation of the system. But we shall see, the new law enacted to implement less than three years, especially in the import and export of food quality safety problems of many doctrine regulation, has yet to be fully in line with international standards, the construction of legal system is not completed. In the field of food safety in our country, especially in the import and export food safety law lags far behind the western developed countries, it is also directly contributing to the China import and export food safety incident frequency, makes food import and export trade in our country in international competition at a disadvantage.

\subsubsection{Food safety science and technology support system lag behind}

Food quality and safety support system refers to the government in the control of food safety regulation depends on scientific basis and technological support. Its core is the use of technical means, in general, the content of the food safety science and technology support system are: scientific risk assessment techniques; The advanced inspection and quarantine technology; The traceability of the early warning technology; The entire monitoring technology.

\subsubsection{The lack of import and export food safety regulatory functions}

The lack of import and export food safety regulatory capacity has always been the weak link in the field of food safety in China. From the perspective of the composition of regulators, import and export food safety supervision and management departments in our country mainly include: general administration of quality supervision, inspection and quarantine of import and export food safety agency, the state food and drug administration, health supervision departments, quality and technology supervision department, the administrative department for industry and commerce, etc. China's import and export food safety regulatory enforcement ability and strength relatively backward, handling imported food is not strong enough, and the level of law enforcement team also needs to improve itself, is also China's import and export food quality security problem is one of the main reasons for frequent

\section{References}

1. Liao Weidong. Regulation on the Public Food Safety: Institutional and Policy Study. Economy \& Management Publishing House,2011.

2. Zhen Guihuan, Wang Shouyang, Xu Shanying, Zhang Xun. China's import and export trade analysis and prediction. Science Publishing Press.2010

3. Zhang Qizi. China's industrial competitiveness report (2012) No. 2.. Social and sciences academic press. 2011

4. Lin Shenqing. Food import and export trade and quality control. Science Publishing Press.2002

5. Shao Jiyong. Food safety and International trade. Chemical industry press.2006 
6. Nie Xuemei, Chu Xiaogang, Li Li, Guo Wei, The discuss on import and export food security issues, trends, and progress. Food safety and inspection[J].2010(1):288-292.

7. Qin Zhenkui, Tang Guangjiang. The situation and prospect on China's food import and export. China's food and nutrition[J].2003(3):15-16.

8. $\mathrm{Xu}$ Yongshan. On the legal issues concerning China's import and export food safety. Journal of Anhui Agriculture University[J].2010(2):77-80.

9. Cheng Jingmin, Sun Yanfei, Yan Guohua, ChengYanrong, Xie Binyu, Guo Yujie. The analysis of 2008-2009 China's food exports to the United States, Japan and the European Union's safety problem. Research on China's health policy[J].2011(3):46-50.

10. Li Huai. Food safety regulation system in developed countries and the implications for China. Journal of Dongbei University of Finance and Economics[J].2005(1):3-8.

11. Wei Yanxia. Food safety problems and legal countermeasures in the international trade. Leal System and Society[J].2008(7):97-98.

12. Wang Yan. Research on the status quo and countermeasures of China's export food safety after entering into the WTO. Hefei University of Technology.2008. 